\title{
THE SOUTH AFRICAN MILITARY IN TRANSITION: PART 2 - FROM STRATEGIC CULTURE TO STRATEGIC REALITY
}

\author{
Gerhard M. Louw \\ South African National Defence Force \\ Abel Esterhuyse \\ Stellenbosch University
}

"Culture is as culture does"1

\begin{abstract}
The analysis reported here focused on the dynamic interaction between a preferred strategic management model of the South African National Defence Force (SANDF) on the one hand, and the SANDF's acquired strategic culture on the other. From a theoretical perspective, the analysis draws attention to the fact that the properties of institutional culture inform the extent to which an organisation (such as the SANDF) suffers the deleterious consequences of an inappropriate management model. The article therefore argues that the military's lack of consensus on an appropriate political culture, the lack of a suitable social culture and the lack of an effective military culture have resulted in maintaining the continued viability of two discrete, concurrent strategic cultural paradigms in the SANDF: that of the defunct $\mathrm{SADF}^{2}$ (initially dominant), and that of the obsolete $\mathrm{MK}^{3}$ (currently governing). The uneasy co-existence of these two paradigms, each with its own worldview and value system, has confounded the efforts of the SANDF to form an appropriate intended strategy and to realise military effectiveness in its execution. A dichotomous strategic culture has, in effect, reinforced the weaknesses of the SANDF's strategic management model, impeded organisational responsiveness, maximised organisational entropy, and encouraged the defence force's systemic decline - the latter, a fact that the Defence Review 2014 specifically acknowledges in the discussion of the review's first milestone. ${ }^{4}$ This part mainly employs deductive reasoning and draws its conclusions from a focused literary review.
\end{abstract}

Scientia Militaria, South African Journal of Military Studies, Vol 42, Nr 2, 2014, pp. 27-53. doi: $10.5787 / 42-2-1093$

\section{Introduction}

Upon examining the defence budget vote speech of 23 May 2013, one comes under the impression that the SANDF is on the 
threshold of a second transformation - this time, aiming at military effectiveness, rather than civil oversight or racial representativeness. ${ }^{5}$ Nevertheless, by the end of 2014 government still had to match its assurances of the previous year with tangible action. Given the mandatory character of defence policy, one may consequently presume that defence leadership of the past decade had not been convinced of the appropriateness of South African defence policy from the beginning, and had never meant to achieve its intended outcomes anyway. ${ }^{6}$ Such an assumption would be premature, though. In continuation of the reasoning reflected in Part 1, the study now argues that the enduring strategic lethargy of the SANDF can instead be explained by the dynamic interaction between defence's preferred strategic management model on the one hand, and its acquired strategic culture(s) on the other. Whereas Part 1 reported on the development of a strategic management archetype for the military (rendered graphically in Figure 1), the second part argues that the strategic culture of an organisation will ultimately determine the extent to which the institution suffers the harmful consequences of adopting an inappropriate management model. Operating from within the organisation, the influence of the defence force's strategic culture would be visible from the formulation of its policy (the Defence Reviews of 1998 and 2014, for example), through to its deliberate implementation, and onwards to the forming of defence's realised strategy.

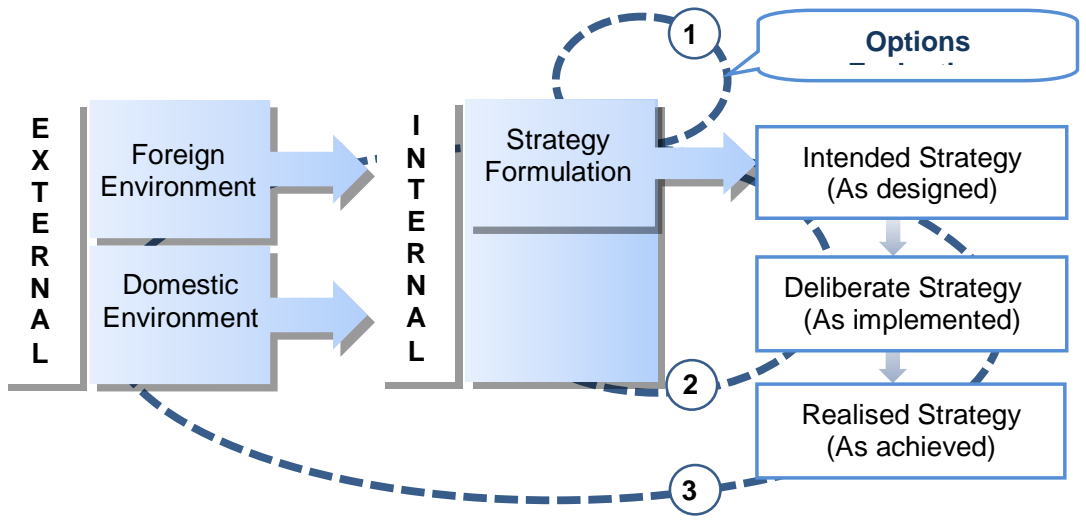

Figure 1: Forming realised strategy

Part 2 of the article therefore delves deeper into the relationship between the strategic management model and strategic culture, starting with the latter idea. 


\section{Strategic culture as an intervening variable}

Most of the available evidence suggests that the concept of a strategic culture is real and powerful. What is debatable, though, is the magnitude of the influence of culture on strategic behaviour. ${ }^{7}$ Some anthropologists and sociologists, for example, consider the relationship between culture and strategy as a combination of discursive (what is said) and non-discursive (what remains unsaid) expressions; consequently, that the relationship between culture and strategy is so complex that it is impossible to measure. ${ }^{8}$ On the other hand, analysts of a constructivist bent consider culture as the major justification for all strategic performance, and would be comfortable with a statement such as "[p]olities as more or less distinctive strategic cultures tend to commit characteristic errors; indeed, their errors may be caused by some of their virtues". ${ }^{9}$ A third approach could be adopted by those who merely consider culture as a supplementary explanation for strategic behaviour, believing that its subjective influence on decision-making is subordinate to the objective constraints of international systemic pressures - in other words, that strategic culture is outranked by the functional imperative. ${ }^{10}$ Whatever one's inclinations are, though, it would be difficult to deny that the response of a particular institution to functional and societal imperatives is at least partly dependent on the values and perceptions (and therefore the societal paradigms) of its decision-makers. This basic fact is implied in Schein's definition of organisational culture:

Culture can now be defined as (a) a pattern of basic assumptions, (b) invented, discovered, or developed by a given group, (c) as it learns to cope with its problems of external adaptation and internal integration, (d) that has worked well enough to be considered valid, and therefore (e) is to be taught to new members as the (f) correct way to perceive, think, or feel in relation to these problems. ${ }^{11}$

With specific reference to strategic culture, Johnston is of the opinion that it consists of an integrated system of symbols (such as argumentation structures, languages, analogies and metaphors), which act to establish strategic preferences for the organisation. It exerts influence by generating paradigms on the role and efficacy of military force in interstate political affairs, and by cloaking the resultant constructs with such an aura of truth that the organisation's strategic preferences seem uniquely sensible and effectual to those immersed within the particular culture. ${ }^{12}$ Strategic culture is therefore a primary component of the organisational imperative, where it serves as an intervening variable between the external environment (the functional and societal imperatives) and the organisation's expression of strategic behaviour. Stated in constructivist terms, strategists subconsciously employ their cultures to assist with their interpretation of the 
objective constraints from their external environment, i.e. creating order from chaos, and comprehension from confusion. ${ }^{13}$ Culture therefore serves both as a perception filter for the realities of the strategic and domestic contexts on the cognitive input side of the organisational imperative, and as a focusing lens on the behavioural output side. This means that any two organisations, distinct in terms of strategic culture, will come to different conclusions when faced with the same set of functional and societal imperatives. To arrive at the reasons why this should be so, one has to turn back to point (b) of Schein's definition and consider the origins of strategic culture.

\begin{tabular}{|ccc|}
\hline Physical Sources & Political Sources & Societal Sources \\
\hline Geography & Historical Experience & Myths and Symbols \\
Climate & Political System & Defining Texts \\
Resources & Elite Beliefs & Generational Change \\
Technology & Military Organisations & \\
$\leftarrow------$ & Transnational Norms & $--------------\rightarrow$ \\
\hline
\end{tabular}

Figure 2: Potential sources of strategic culture ${ }^{14}$

For a start, one may generalise that strategic culture is rooted in the relevant community's early, seminal experiences, and that the viability of the culture is dependent upon inspiration by its opinion-forming elites and the philosophical and cognitive characteristics of the state..$^{15}$ On the other hand, one may be more specific and expand the sources of strategic culture into a full typology, comprised of both ideational and material elements, as per the example above. The differences among strategic cultures are therefore consistent with the variance in their sources. Societies may, for example, share a common geographic area, climate and natural resource base (material factors), but very little content from the other elements (ideational factors) from which they source their cultures. While the import of most of the listed sources should be self-explanatory to the informed reader, the study may benefit from an elaboration on some of the origins of strategic culture at this time. Technology is the first of these.

Some authors argue that armed forces bring about military change primarily by their constant search for a combat advantage and their consequent adoption of new technologies and ways of conducting warfare. Others dispute this determinist view of technology, and contend that societies and organisations differ substantially 
in their ability to exploit new technologies, create new operational concepts and reorganise their armed forces to take full advantage of the opportunities that technology offers. ${ }^{16}$ As a source of inspiration for a strategic culture, one can therefore only appreciate the influence of technology within the context of that particular military's historical experience, its defence organisation, and its preferred style of warfare - the totality of its strategic culture, in other words. For example, armed forces that idealise conventional war and manoeuvre warfare ${ }^{17}$ (as the SADF had been doing by the late 1980s) ${ }^{18}$ would assess the value of technology differently from those espousing revolutionary war or guerrilla warfare (as the MK had been doing all along). ${ }^{19}$ To the former, increased technological sophistication would have allowed for a reduction in force levels, while to the latter it may not have meant much in terms of improved military effectiveness. In fact, to MK it may have entailed an unacceptable reduction of the revolutionary forces' footprint among the population in the operational area. Whether defence forces are therefore able to manage and manipulate technology to their advantage depends on a combination of organisational attributes, which yet another source of strategic culture seems to be affecting of late, namely generational change.

Strategic culture changes over time as the security community develops new understandings, translates them culturally, and programmes the result into behaviour. ${ }^{20}$ With the arrival of (especially) information technology in the late $20^{\text {th }}$ century, for example, individuals and groups are finding themselves empowered and their identities shaped - in ways that were unthinkable before. ${ }^{21}$ These changes to societal culture, which the ubiquitous presence of information technology has accelerated, are bound to affect every military eventually. Indeed, generational change is believed to be the most consistent (albeit not the most rapid) driver of cultural transformation, and is only rarely interrupted by other conditions that may cause more rapid changes in strategic culture. ${ }^{22}$ Taking the SANDF as an example, one has to consider that it had not been involved in major combat since its establishment. Circumstances conducive to brisk, collective culture change have therefore not arisen in this case, and one would imagine that the strategic cultures of the defence force's primary constituents could have remained largely intact, awaiting generational change to transform the SANDF's organisational culture as a whole. From the above, it seems clear that defence forces with different sources of inspiration would have distinctly different strategic cultures, and therefore different strategic preferences and behaviours as well. Through an analysis of those preferences and their expressions in policy statements, it should therefore be possible to obtain usable indications of the particular military's intended force development strategy, and hence of its strategic culture as well. While setting out a 
rationale for this deduction, the article will also begin to contextualise some of the theoretical concepts that had been touched upon earlier.

\section{Military strategy as a product of strategic culture and management model}

As explained in Part 1 of the article, strategy and policy are so intimately related that their formation processes can be regarded as virtually identical. Baylis, Booth, Garnett and Williams, for example, assert that a policy connotes not only what it intends to achieve (strategy's ends), but also with what occurs during its actual implementation (strategy's means and ways), and that a policy without action will have no authority in the society that it is supposed to direct. In practice, one can accordingly think of defence policy as a stream of purposeful action over time, incorporating not only what the department is known to have done, but also what it intends doing, and what it is currently trying to do. ${ }^{23}$ Defence policy gives birth to two concurrent types of military strategy - operational strategy, based upon current military capabilities, and force developmental strategy (the focus of this article), which addresses future security threats and military tasks with future capabilities. ${ }^{24}$ A suitable definition of military strategy should therefore encompass both types, which is why strategy is defined in this article as the "relating of ends, means and ways to achieve the desired [defence] policy goal". ${ }^{25}$ Militaries tend to categorise strategy as being declaratory (what government and the armed forces say the strategy is), actual (what government and the armed forces are essentially doing, which may be different from their declared position), and ideal (what the decisionmakers would prefer to do if they had access to the necessary means). ${ }^{26}$ Compared with Mintzberg's typology (see Part 1 of this article), a military's declaratory strategy would correlate with an intended strategy, while the actual strategy would be equivalent to a deliberate strategy. Both forms of strategy are eminently suited for employment within a design school management model, and both are subject to the influences of an organisation's strategic culture. To arrive at a declaratory strategy in the first place, military decision-makers would have had to evaluate their strategic options, and consciously selected the option that best passed the tests of suitability, feasibility and (especially) the culture-constrained test of acceptability. In accordance with design school management methodology, the armed forces would then implement (not 'achieve') their intended strategy, believing that its realisation is merely a matter of proper execution. Even if this belief were unfounded (which it is, more often than not), a defence force that was responsive to feedback loops would still have addressed the disparity between its declared policy position and changing reality, and thereby guided its actual strategy towards the realisation of outcomes that at least largely resemble those of the organisation's intended strategy. $^{27}$ 
In Part 1, a potential explanation for the SANDF's failure in this regard was already suggested, when reference was made to the design school approach of confining the military strategist to formulation of strategy only. This management style precludes the strategist's active participation in strategy implementation, which substantially increases the enterprise risk of realising unintended outcomes. For example, misperceptions between strategists and implementers regarding the original principles and purpose of the strategy may, in the absence of continuous strategic leadership interventions, cause the latter to revert to simplistic, incoherent pragmatism. This gives rise to a morbid situation, within which management would be prone to confusing expediency with effective governance. ${ }^{28} \mathrm{~A}$ second, related flaw is that the design school, by definition, disregards the possibility of strategy formulation (strategic thinking) continuing in parallel with implementation of strategy (strategic action). Adherents of the design school are therefore not amenable to the incrementalism that successful strategy formation requires. ${ }^{29}$ Furthermore, by reducing the influences of the external environment to the mere identification of opportunities and threats they exacerbate this failing. While design school strategists' interpretations of the external environment (subject to the filters of strategic culture as they are) may yet serve as inputs into the formulation of their intended strategy, this information is not utilised consistently afterwards as important considerations in the strategic management process. Military strategists may therefore be inclined to account for functional and societal imperatives during strategy formulation only, viewing such imperatives afterward merely as factors through which the organisation must navigate, rather than as evolutionary stimuli with which defence leadership should interact. ${ }^{30}$ Such a snapshot approach to the external environment also implies that, though the design school's strategic management framework may never become outdated, it could easily go out of context and become irrelevant with the passage of time - as had evidently happened in the case of the SANDF. ${ }^{31}$

It is entirely plausible that the filters of the SANDF's strategic culture had distinguished between those events in the external environment that it deemed cardinal, demanding a rapid response, and those it regarded as insignificant and of secondary interest. Consequently, the strategic behaviour of the organisation followed suit, giving rise to a realised strategy with which the organisation was at least psychologically comfortable, regardless of the perceived functional effectiveness of defence. What usually happens in cases such as these is that, as the intended (declaratory) strategy becomes increasingly out of step with the demands of the organisation's external environment, an emergent strategy largely supersedes it. Such an emergent strategy would neither be entirely intentional nor deliberate; it would rather be an inferred strategy, based on empirical evidence that the actions or 
neglect of the organisation had, over time, been converging into identifiable trends and predictable outcomes, whether premeditated and desirable or not. ${ }^{32}$ In terms of VSM theory (introduced in Part 1), the proliferation of emergent strategy indicates that an organisation had reverted to its native cultural values and purposes-in-use, instead of adhering to an intended strategy that the institution had previously created and professed to. This form of strategic behaviour is often encouraged by deficient internal discussions on the larger purpose of the institution, namely debates that are lacking, inadequate or poorly grounded in the daily conduct of the personnel of the organisation. ${ }^{33}$ Given that the attribute of military effectiveness is an essential outcome of any reputable defence force's overarching strategy - and features accordingly in the South African Defence Reviews of 1998 and 2014 - effectiveness will now be located within the strategic management model that has been developed thus far.

\section{Military effectiveness as an outcome of realised strategy}

In spite of its potential importance for state security, literature on military effectiveness does not provide a generally acceptable definition for the concept. ${ }^{34}$ Brooks and Stanley describe it as "... the capacity to create military power from a state's basic resources in wealth, technology, population size, and human capital". ${ }^{35}$ This definition accentuates military power as an absolute, but fails to acknowledge the relevance of the strategic imperatives discussed previously. On the other hand, Millett, Murray and Watman define military effectiveness as "... the process by which armed forces convert resources into fighting power", thereby confining military effectiveness to its expression in combat only. ${ }^{36}$ The latter definition is also inadequate, because it focuses exclusively on the method and fails to account for the purpose of the particular defence force, relative to the military problem on hand (the 'ends' of strategy). ${ }^{37}$ In their description of military effectiveness as a resource conversion process (not a strategic outcome), both definitions appear to emphasise the quantifiable attribute of organisational efficiency rather than that of effectiveness - a concern with executing activities correctly, as opposed to performing the correct activities. In lieu of an acceptable definition from literature, this article consequently reflects on military effectiveness simply as the competency of armed forces to produce a desired or intended result, i.e. the ability to execute the mission of defence successfully, in reasonable disregard of absolute resource cost. However, one should not assume that defence policy and (especially) military force development strategy always have operational effectiveness as their only goal.

Countries invest in the creation and maintenance of armed forces for any combination of reasons, including the enhancement of their national identities, the legitimacy of government, international status, or leveraging diplomatic advantage. ${ }^{38}$ 
Aside from military effectiveness, realised strategy may therefore contain traces of all of these strategic 'ends' originating from the host society's culture, its social structure, its political and economic institutions, and from international factors such as global 'mental models' and competition among states. ${ }^{39}$ Nonetheless, it would still be possible to derive the extent of the SANDF's military's effectiveness from an analysis of its realised strategy by applying only four tests: those of integration, quality, skill and responsiveness. ${ }^{40}$ The test for integration relates to the 'ends' of strategy, as the assessment seeks a verdict on the degree to which the management behaviours of a military are internally consistent and mutually reinforcing. Integration assumes a unity of purpose between force development activities (premised upon future defence requirements) and the current execution of the roles, functions and tasks of the military. By ensuring that actual objectives of defence are in alignment with its declared aims, integration reduces wasteful expenditure and duplication of effort. The test for quality, on the other hand, is concerned with strategic 'means'. Quality refers to the ability of a military to acquire weaponry and equipment that are not only superior in terms of function, relative to that of the opposition, but also optimised for the current (and plausible future) operational context of defence. Quality associates with the cost-efficiency of means, since it guides the organisation's internal management and procurement processes to acquire only that which the military actually needs.

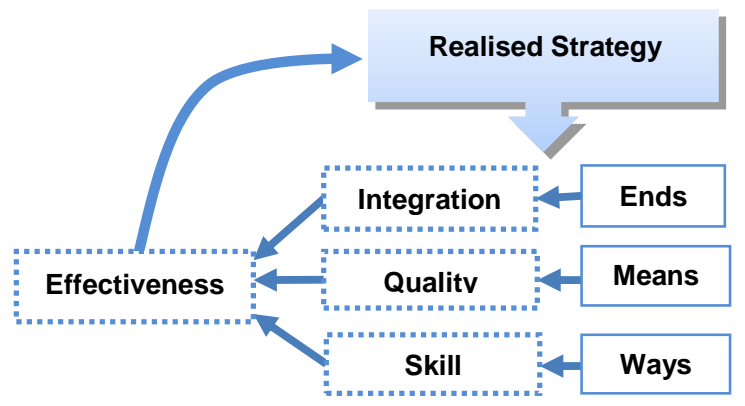

\section{Figure 3: Evaluating realised strategy}

Likewise, the attribute of skill refers to the competency of military personnel in the execution of their designated tasks. Skill concerns the inculcation of proficiency through training, education and appropriate experience. It also refers to the ability of the military to assimilate new technology, as well as the attitude, morale and motivation of its personnel - in other words, considerations of professional expertise and the service orientations of defence's workforce. As 
depicted in Figure 3, a military's overarching level of skill would constrain the 'ways' available to defence when it considers strategic options.

Unlike an evaluation of the appropriateness of a strategy (discussed in Part 1), the gauging of military effectiveness does not seek to render an anticipatory verdict of intended strategy, which is a mere theoretical construct at the time of its judgement. As was explained previously, the strategic environment changes continuously; hence, military effectiveness is context-dependent and varies across time, place and the type of mission that the particular military has to execute (or potentially has to accomplish). ${ }^{41}$ When the article therefore touches upon the last of Brooks and Stanley's characteristics - that of responsiveness - reference is made to the ability of a military to customise its activities in the light of its own competencies (organisational imperatives), the operational capabilities of adversaries (functional imperatives), and other external constraints. A responsive military is "... one that adjusts its operational doctrine and tactics to exploit its adversary's weaknesses and its own strengths" and "... one that adjusts and compensates for external constraints, including material, geographic, technological, social-structural, political, or cultural limitations in its domestic environment". ${ }^{42}$ To maintain military effectiveness, a responsive defence leadership will continuously scan the political and strategic environment and adjust its policy, strategy, doctrine and management processes accordingly. In contrast, "[m]ilitaries without responsiveness may lose an accurate sense of their particular strengths and weaknesses because of a lack of critical self-evaluation and of rigorous assessment of the external environment" 43 - precisely those internal debates previously referred to. The attribute of organisational responsiveness is therefore much more significant than its simplistic application as one of the tests for the effectiveness of realised strategy would seem to indicate. It originates within the organisational imperative, where the institution's strategic culture resides, and shapes both the receptiveness of defence to environmental influences and the reactions of defence to the same. As discussed thus far, responsiveness is implicit in every aspect of dynamic organisational behaviour. A military's reactions to its operating environment are the prime stimuli for its organisational learning and crucial for the successful evolution of the organisation. Before arriving at a comprehensive hypothesis that could explain the SANDF's organisational entropy and declining military effectiveness, though, a speculative validation of the main arguments is put forth, as the authors have promised. The following section therefore contains an overview of the development of the SANDF's strategic culture. 


\section{A dichotomous strategic culture: The SANDF's primary source of strategic stasis}

For the first decade of its existence, government deliberately subjected the SANDF to cultural reprogramming: an epic exercise in social engineering, of which the full implications are only lately being realised (as a result of the delays implicit in all feedback loops). Given the cultural hegemony, administrative monopoly and exclusive ownership of material resources of the former South African Defence Force (SADF), government initially feared that its culture and methodology would remain dominant in the contemporary national defence force. Four years after the start of transformation, some of the smaller integrating forces were consequently still of the opinion that they were being absorbed by the SADF, rather than being equitably integrated into a new defence organisation. ${ }^{44}$ In its efforts to change and consolidate the strategic culture of the military, government therefore generated a new political vision for the SANDF: the institution was to be "... broadly representative of the country's people at all rank levels, where all people feel at home, a defence force of national unity that is credible and legitimate in the eyes of all our people". 45 This novel organisational culture centred on the respect of the military for the values of a democratic society and directed national defence -

- "to ensure that the functioning of the Department of Defence is consistent with constitutional principles, democratic values and the law;

- to ensure that military personnel treat each other and members of the public with respect and dignity;

- to maintain and enhance military professionalism;

- to build confidence and pride in the SANDF; and

- to build patriotism, loyalty, unity, discipline, morale and combat readiness within the SANDF". ${ }^{4}$

Political leadership was therefore intent upon 'software' changes, designed to transform the ways by which defence managed its human resources, as well as changing its institutional culture and the military ethos. ${ }^{47}$ Consequently, the SANDF had an internal, structural focus, dedicating itself to the deliberate transformation of the organisation, and aiming primarily at the legitimation of the national defence function rather than ensuring the capability of the military to execute its constitutional mandate. ${ }^{48}$ Since the country had just come out of a conflict that had lasted for about three decades, the fact that neither the political vision nor the intended transformation objectives listed above (with the exception of the last) supported the creation of military effectiveness was possibly of lesser importance at the time. However, this does not imply that the professed values of the country's new-found political system would have remained the primary source of strategic culture for the SANDF ad infinitum. To illustrate, Francois Vreÿ wrote an article in 
2006 - roughly a decade after the establishment of the SANDF - that dealt extensively with the evolution of a South African strategic culture, albeit at national level. In this article, he emphasises some of the changes that accompanied the birth of the new dispensation:

- An innovative, liberal political culture, founded on international norms and human rights;

- A foreign policy enamoured with multilateralism, collective defence, and African solidarity; and

- The subordination of the military instrument to other elements of national power, focusing on conflict prevention and state reconstruction.

At the same time, some of the contradictions between declaratory policy and strategic behaviour (which Vreÿ calls "operational practice") were already becoming apparent. ${ }^{49}$ These include the acquisition of advanced weaponry for the air force and navy, on the military side, but it also refers to South Africa's apparent willingness to intervene (virtually) unilaterally in the affairs of Lesotho (1998) and Burundi (2002). Of greater concern, though, was the apparent lack of political will to pronounce on human rights violations elsewhere in Africa. In fact, some analysts were of the opinion that the apparent dichotomy was the result of South Africa having to contend with two competing political cultures simultaneously - the professed culture of a progressive democracy on the one hand, and the actual values of a revolutionary liberation movement on the other. ${ }^{50}$ While a dichotomous political culture is worthy of an investigation all of its own, the current study was predominantly interested in the effects of a divided strategic culture on military strategy formation of the SANDF. To tell that story, one would have to direct the analysis one level down, to statements of defence policy intent and what those statements implied for realised strategy.

There were early indications that, with the passage of time and the deliberate implementation of force development strategies, the transformation focus of the SANDF was shifting away from its declared aim. Whereas the original goal was to effect appropriate changes to defence policy, military ethos and organisational structure, the parliamentary committees and the new command cadre of the military were increasingly preoccupied with simplistic racial representation - a strategic intent for which the Deputy Minister of Defence was not about to apologise any time soon, ${ }^{51}$ and which promptly made 'transformation' synonymous with racial representativeness. ${ }^{52}$ While this bias would have been unsurprising, given South Africa's political proclivities in the past, the country's overt pursuance of racial representativeness by politician and defence leadership alike was bound to affect, perhaps inadvertently, the strategic culture of the SANDF significantly. Upon the establishment of the SANDF in 1994, the armed forces were overwhelmingly 
comprised of white personnel from the now-defunct SADF: a reasonably homogenous social group, with a distinct historical experience, a characteristic set of myths and symbols, and defining texts - in other words, unique sources of the SADF's strategic culture. This context was due for brisk, deliberate change thereafter. Despite the fact that "... the former SADF has clearly been in the driving seat", the racial composition of the defence force had already changed to $29 \%$ black officers and $70 \%$ black 'other ranks' by $1998 .{ }^{53}$ By 2011 , the percentage representation (including civilian personnel) stood at 70,6\% black, 12,6\% coloured, $1,1 \%$ Asian, and $15,7 \%$ white, $^{54}$ changing to $71,8 \%, 12,7 \%, 1,1 \%$ and $14,2 \%$ respectively two years later. ${ }^{55}$ Considering that the current study was especially interested in those levels where military strategy is formulated, the racial composition of the Department of Defence's (DOD's) strategists and corps of professionals (the latter included for the sake of completeness) had changed likewise, with the black group, in particular, very strongly represented in top management by then. Figure 4 substantiates these demographic trends.

\begin{tabular}{|lrrrrr|}
\hline $\begin{array}{l}\text { Occupational } \\
\text { Band }\end{array}$ & Black & Coloured & Asian & White & $\begin{array}{c}\text { Total } \\
(100 \%)\end{array}$ \\
\hline Top Management & 29 & 0 & $\begin{array}{r}1 \\
(85,3 \%)\end{array}$ & $\begin{array}{r}4 \\
(0 \%)\end{array}$ & 34 \\
Senior & 199 & 16 & 22 & 130 & 367 \\
Management & $(54,2 \%)$ & $(4,3 \%)$ & $(6 \%)$ & $(35,4 \%)$ & \\
Professionally & 4183 & 1109 & 270 & 4158 & 9720 \\
Qualified & $(43 \%)$ & $(11,4 \%)$ & $(2,8 \%)$ & $(42,8 \%)$ & 10121 \\
\hline Total & 4411 & $\mathbf{1 1 2 5}$ & $\mathbf{2 9 3}$ & $\mathbf{4 2 9 2}$ & $\mathbf{1 0}$ \\
\hline
\end{tabular}

Figure 4: Demographic representation in the DOD by $2011^{56}$

By this time, defence had already explained the over-representation of white personnel in senior management as a consequence of "historical reasons", and that white officers either had to resign or retire to release posts for blacks at this occupational level. ${ }^{57}$ Clearly, a sweeping change in the SANDF's demography since its founding would have been accompanied by a major alteration in the social sources of its organisational culture as well, especially in a South Africa where communal cultures were perceived (and forced to evolve) along racial lines for almost half a century before democratisation. For two reasons, though, this claim does not automatically imply that the traditional black (predominantly African) social culture has entirely superseded the archetypal white (predominantly Western) culture of the SANDF since then. The first argument is based upon simple arithmetic, where the table above provides evidence that there are still many senior 
white officers remaining in - especially - senior management posts in the SANDF. In these positions, one can expect them still to have a substantial, albeit everdiminishing, influence upon strategic planning. However, Figure 4 reveals that the same argument does not apply to the vital activity of strategic visioning, which is a function of top management and where the African culture is dominant. Secondly, the armed forces as a whole would have been subject to generational change in all of its constituent cultures, Western and African, over time. The cultures of South African society would have been changing qualitatively since 1994, and those of defence's constituent race groups would have paralleled the gradual convergence of the nation at large. Nevertheless, the differences between the two prevalent social cultures would have been much more visible during the first years of the SANDF's existence. The values and norms of these two original cultures were bound to have been in a tacit, imperceptible, intuitive competition with each other from the very beginning, and the constant tension between the dominant social cultures would have been enough to create vacillation and ambiguity in the formation of strategy. Given that defence sources its strategic culture from social culture as well, and that strategic culture guides both the institution's perceptions of strategic reality and the direction of its strategic behaviour, this article could plausibly attribute at least part of the SANDF's current stasis to this conflicted organisational culture. The prognosis for military effectiveness becomes worse when one considers yet another source of the SANDF's strategic culture(s): that of former military force affiliations, each with its particular historical experiences, organisational structures, myths and symbols.

The co-existence of a number of strategic cultures within a defence force is normal if the divisions run along vertical or functional lines (as with the ethos differences among the services, for example). ${ }^{58}$ In the case of the SANDF, however, this article argues that the cultural rifts tended to stretch horizontally within the strategy-making bodies of the organisation right from the start. Assuming the early dominance of the former SADF, one would expect to find evidence of its militarystrategic preferences in defence policy publications of that time - and so it is, indeed. Three policy prescripts, in particular, provide clues to the conventional cultural bias of the SANDF's strategists in 1996. First, there is the injunction that the force levels, armaments and expenditure of the military shall be determined by defence policy, as derived from (among others) an analysis of the external and internal security environment. ${ }^{59}$ This statement, logical and pragmatic as it appears to be in theory, indicates compliance with the dynamic school's approach to strategic management, encourages reasoned flexibility, and gives credence to feedback from the external environment. In practice, though, the extraordinary delay in producing a revised defence review - a symptom of the SANDF's increasing 
entropy - trivialises the original policy statement and negates the formation of an appropriate military strategy. Moreover, the original defence policy envisaged that the "SANDF shall be a balanced, modern, affordable and technologically advanced military force, capable of executing its tasks effectively and efficiently". ${ }^{60}$ Apart from the fact that the latter proclamation contains adjectives - "balanced", "affordable" and "technologically advanced", for example - that would be difficult to reconcile in a real world with limited resources, it also contradicts the pragmatism of the previous statement. Its directive tone is indicative of a technocratic paradigm, supportive of traditional military dogma, and leaving little room for innovative adaptations to environmental realities. From the evidence available (some of which the article referred to in the introduction), this intended strategic outcome, too, failed to realise. Likewise, the third statement dispels any further doubt regarding the strategists' preconceptions, by saying that the primary role of the SANDF "shall be to defend South Africa against external military aggression" - a contingency that the defence fraternity has never faced since the establishment of the Union Defence Force in 1912, and which is still highly implausible one hundred years later. ${ }^{61}$ In combination with other pronouncements in the 1996 White Paper and the 1998 Defence Review, these three policy prescripts point to the superior weight of functional imperatives in the formulation of policy and declaratory military strategy. The questions now begging answers are therefore:

- Why were these prescripts, so indicative of the expired SADF's conventional warfare paradigm, given such prominence in defence policy; and

- Why were the prescripts not adhered to during implementation of strategy?

Whereas a follow-on study should attempt to supply comprehensive answers to these questions, the current study only attempted to provide some avenues for investigation.

The first hint regarding the reasons for the prominence of the functional imperative in defence policy arises from what Rocky Williams calls "the strong ascriptive affinities that exist between many armed forces of the developing world and the intellectual discourses of the former [Western] colonisers". ${ }^{2}$ Had these affinities dominated the SANDF's strategic thinking, though, defence would probably have adopted the transformation pathway of emulation, and modelled itself exclusively upon the types of equipment, operational concepts and techniques used by other, idealised defence organisations. ${ }^{63}$ Instead, the notion that the bulk of the tactics, techniques and practices of the former non-statutory forces - and especially those at the operational level of warfare - would not have been fitting in a modern defence force, and especially not in the force design template of the SADF of yore, 
seems to have held sway. As was intimated previously, the continuation of the former SADF's military practices was also encouraged by the fact that, at the time when defence introduced its new policy, the SADF's command structure was still very much in charge and was using its pre-existing infrastructure, instructors and training institutions to conduct the SANDF's force development. Turning to the glaring absence of defence policy prescripts in realised strategy, one could argue that the intended conversion of (especially) the former revolutionary forces to the new military paradigm that the policy prescribed was merely a pragmatic, tactful, facesaving illusion - at least, insofar as the former SADF's ideological competitors were concerned. In this case, much of defence policy's drive towards military effectiveness would boil down to mere utilitarian constructs, which stakeholders superficially maintained to enhance all of the integrating forces' self-worth, to avoid defensive responses, to encourage the relationship-building process, and ultimately to ensure the successful melding of the former forces into one unified institution. ${ }^{64}$ In situations such as these, existing cultural rules regarding interaction and communication dictate that the actors will readily sacrifice collaboration and understanding to preserve their respective reputations. ${ }^{65}$ However, these charades would also have had other deleterious consequences, in that they would have suppressed the type of honest and exhaustive debates that stand central to learning organisations. In this manner, the SANDF's adoption of a novel, shared strategic culture had been obstructed in the past, and may still be delayed in the present.

One finds evidence in support of this theory in the fledgling SANDF of the late 1990s, where each of the integrating forces were ostensibly treated as if they were all at the same level of military professionalism, had equally viable military doctrines, and had been equally successful in achieving their military objectives. ${ }^{66}$ This was especially true in the case of the relationship between the SADF and MK the predecessor regime's defence force and the ruling party's military force, respectively - when the Chief of the SADF and the Chief of Staff MK served as cochairs of the Joint Military Co-ordinating Council. ${ }^{67}$ In spite of the patent disparities between the SADF and the other integrating militaries, this power balancing was a necessary machination, given that the revolutionary forces had clearly won the political struggle and were now in power despite the SADF remaining undefeated in combat. Given the adage that it often takes a beating for an armed force to adjust substantively to the actual conditions of war, ${ }^{68}$ one may well ask which of the two primary antagonists (the SADF or MK) perceived themselves to have been either the vanquished or the victors, and therefore obliged to adopt a more functional military theory. Colin Gray is of the opinion that, in strategy, nothing fails like success, because the victor becomes unjustifiably persuaded of his or her genius or of the favour of the gods. ${ }^{69}$ The article therefore argues that the lack of closure on issues of 
an appropriate political culture, a suitable social culture, and an effective military culture contrived to maintain the viability of two discrete, concurrent, horizontally stratified strategic cultural paradigms in the SANDF: that of the defunct SADF (initially dominant) and that of the obsolete MK (currently governing) ${ }^{70}$ The uneasy co-existence of these two paradigms, each with its own worldview and value system, but within the same organisational imperative, would have confounded the SANDF's efforts to form an appropriate strategy indefinitely. Moreover, the SANDF's preferred strategic management model may have contributed further to the stasis that, after almost two decades of transformation, is becoming more apparent in defence's realised strategy by the day. ${ }^{71}$ To validate this assertion, the article will again, as in Part 1, resort to Henry Mintzberg's criticism of the design school management approach.

\section{Strategy formation by design: The SANDF's primary method towards strategic stasis}

Mintzberg is of the opinion that strategists of the design school - whose generic approach the SANDF is presumed to have been using - are liable to detach thinking from acting, to encourage managers to remain aloof from the ground-level activities of the business, to oversimplify strategy, and to deny its formation as being a long, subtle and difficult process of organisational learning. ${ }^{72}$ Nonetheless, Mintzberg also recognises that the design school's method of strategy formation may be more viable in certain situations. The first condition for success is that, in principle, one mind should be able to deal with all of the information relevant to the formation of strategy. The organisation's functional context should therefore be relatively simple, allowing for an unambiguous definition of the strategic problem a setting which the transformation of the SANDF, in all of its complexity, certainly did not provide. A second, related stipulation is that strategists at the top should have sufficient access to and experience of the competencies of the institution and its operating environment. To buttress their potential monopolisation of strategy formulation, strategists should thus be insiders, and have constructed a deep, intimate knowledge of both the organisation and the intricacies of its current circumstance over a substantial period. ${ }^{73}$ Again, a study of SANDF internal communication bulletins reveals that this condition, too, did not apply to the organisation during the early years of its transition. In fact, the situation was "extremely complex". ${ }^{74}$ As early as 1998, the Deputy Minister of Defence admitted,

[t]he problems or $[s i c]$ merging into a new SANDF, and of transforming the inherited institution, have proven to be a monumental challenge. This is exemplified by the perception or perhaps fear of former TBVC [Transkei, Bophuthatswana, Venda 
and Ciskei] and NSF [non-statutory forces] members that they are being absorbed by the old SADF rather than experiencing an evenhanded integration of all members - the SADF included - into a new force. $^{75}$

Considering the interest of this article in military effectiveness, the SANDF even then (1998) suffered from a dubious (operational) role definition, institutional overstretch, and a severe case of transformation fatigue: arguably, symptoms of unsuitable strategic ends, inadequate strategic means, and inappropriate strategic ways. ${ }^{76}$ In considering what the article has addressed before, one therefore immediately appreciates the SANDF's long-term strategic management challenge: the environmental context of the SANDF would not have conformed to the caveats for prescriptive strategy formation in the youthful days of the institution, and the SANDF would have had to be exceptionally competent at organisational learning to have become compliant since then.

A third condition for the successful application of a design strategy method is that the strategist should have validated the stability of Mintzberg's first two criteria (mentioned above), before implementing intended strategy of the organisation. Within this relatively stable context, planners should have a clear understanding of current functional, societal and organisational imperatives, and be able to predict with confidence the future changes that will come about in these domains - all of this, to ensure that the organisation's intended strategies remain relevant well beyond their implementation date. ${ }^{77}$ This condition is necessary because strategists of the design school are, by definition, ideologically constrained, less responsive to the influences of (especially) the external environment, and therefore less amenable to the exploitation of emergent events. However, it would hardly have been plausible for the SANDF to know the future when it compiled the 1998 Defence Review, while it was already acquiring a suite of heavy combat systems for the SA Air Force and the SA Navy - this, for a country that had always been oriented towards a landward threat. ${ }^{78}$ Moreover, in its first decade of existence one could scarcely have considered the SANDF as being in a state of stable equilibrium. Within the short space of a few years, the external and internal environments of the Department of Defence were changing radically with alterations in social and political paradigms, adjustments to policy, and major amendments to defence structures. ${ }^{79}$ Yet, even in this volatile environment, politicians were informing the citizenry and its armed forces that, in typical design school style,

[t]ransformation and change represents a territory which can only be successfully traversed when everyone is clear about our goals, puts shoulder to the wheel, and strives as part of a united winning team in 
a spirit of co-operation and trust. Sound policy, implemented throughout a willing institution, by means of effective structures and attitudes, will ensure the success of transformation. Transformation is on track and we will achieve our objectives. ${ }^{80}$

The SANDF, too, was apparently convinced that the realisation of its intended transformation strategy was purely dependent upon the formulation of unambiguous ends and the application of a highly elaborated, systematic, prescriptive method to achieve the same. ${ }^{81}$ This approach, espoused by politicians and military professionals alike, implied that the strategists' individual learning would have ended, and their intended strategy fully explicated, before implementation could have commenced. In this manner, the SANDF seems to have negated the benefits of organisational responsiveness to its external environment, and vaccinated itself against organisational learning as well - both effects being unintended and incidental consequences of adopting an inappropriate strategic management model. Nonetheless, the poor prognosis for the SANDF's transformation strategy becomes worse when one considers the last of Mintzberg's criteria for the successful employment of the design school philosophy: that the organisation should be willing and prepared to cope with a centrally articulated strategy right from the start. Influential members of the organisation should not only be ready to defer to the principal strategists, but should also have the time, energy, resources and emotional commitment to implement the declared strategy. ${ }^{82}$ The SANDF has been aware of this proviso all along, as evidenced by its early comments on transformation management.

International studies reveal that not many large institutions or organisations are very successful at profound transformation, despite their good intentions. Why is this? Is a large and complex organisation such as ours doomed to a similar fate? It is submitted that such failures mainly lie in the area of change management. In most cases, the more technical aspects - designing and implementing new and sound processes, structures and systems - are well executed by competent people. The lack of success seems to be as a result of the failure by the organisation's executives to enlist employee support. Studies seem to point to the requirement for an understandable change message to employees, in particular as seen from their point of view. Employees' concerns have to be addressed. Executives, and not lower level managers, should help people to visualise their contributions to change. This needs to be addressed throughout the implementation and continuously reaffirmed. Executives are to be seen as leading and showing the way. ${ }^{83}$ 
The article has already confirmed that the SANDF's initial transformation had occurred within a bipolar cultural context. This environment allowed for the formulation of a declaratory statement of defence policy, largely based on the values and norms of the defunct SADF, but at odds with the subsequent formation of an pragmatic, deliberate military strategy. Whereas defence policy and the structures of the SANDF - still overwhelmingly staffed by former SADF members - were mainly intent upon achieving military effectiveness and cost-efficiency, political leadership (presumably speaking on behalf of personnel from the other integrating forces) had fundamental emotive and socio-economic goals in mind. ${ }^{84}$ Thus, for the members of the former SADF, a transformed defence function possibly meant that the "SANDF shall be a balanced, modern, affordable and technologically advanced military force, capable of executing its tasks effectively and efficiently", as promised by defence policy. ${ }^{85}$ For the other constituents, though, transformation could primarily have denoted a defence organisation that was representative of South Africa's racial demography, that treated its members fairly, attended to their conditions of service and physiological needs, paid them regularly, and raised their social status "... to the levels s/he deserves ...". ${ }^{86}$ Having had their basic needs satisfied all along, the former SADF complement fixated upon functional imperatives, while (especially) the former non-statutory forces were preoccupied with societal and organisational imperatives. Presented with these substantial differences in the expectations and institutional/occupational orientations of the two dominant cultures in the SANDF, it would have been extremely difficult for the organisation to create those salutary conditions for strategy by design that Mintzberg describes. It would also have been virtually impossible to establish de facto consensus on the integration of the ends of the transformation strategy, agreement on the quality of equipment needed, and acceptance of the actual skills sets required for the SANDF - all of which military effectiveness theory demands.

From the elaboration above, it seems clear that the design school method was not suitable for employment within the first decade of the establishment of the SANDF. However, this does not mean that the particular approach to strategic management may not have become more viable since then. After all, the constraints of the SANDF's strategic context have been changing continuously for about two decades now, providing the organisation with sufficient opportunity to respond appropriately. For example, Mintzberg is of the opinion that the design school's model is eminently suitable for an organisation that is entering a period of reconceptualisation, providing that its functional context displays the following characteristics. Firstly, the environment that previously supported and maintained the former strategy of the organisation has changed drastically, so that the strategic plans of the organisation are no longer viable; and secondly, the organisation has 
already entered a period of relative stability, which will support a new conception of its strategy. ${ }^{87}$

The design school model, therefore, seems most applicable to an organisation that has just come out of a period of flux (the SANDF's "transformation") and into one of operating stability. While a major realignment of strategy usually occurs as a response to a crisis or challenge in the external environment (such as the SANDF's "Battle of Bangui"), an organisation may also embark upon reformation proactively, for instance when key uncertainties are resolved, or when a maximum period has elapsed since the last strategy review. This article contends that such periods had occurred in the SANDF's recent history. The SA Army, for instance, agrees that its initial generalist strategic focus on the integration of the former forces (and its accompanying inculcation of a human rights culture) had officially petered out prior to 2006 already. Consequently, the army then re-focused its force development strategy towards the achievement of military effectiveness, by introducing the first iteration of what was to become its "future strategy" at that time. ${ }^{88}$ This period also coincided with other signs that the SANDF was ready for an evolutionary adjustment, as evidenced by the DOD's abortive efforts to adjust the 1998 Defence Review since then (e.g. Defence Update 2005). ${ }^{89}$ However, the mere fact that the SANDF was still purported to be relatively ineffective by 2013, and that the new Defence Review still had to pass muster in parliament by the end of 2014, implies that something other than the SANDF's strategic management model may be impeding the organisation's responsiveness. It is possible that the first, interim stage of the defence force's declaratory transformation strategy - with its focus on racial and former force representation, workplace liberalisation and cultural reform - may have evolved into its ultimate, realised strategy by default. Mintzberg supports the view that the clear enunciation of strategy, coupled with a machine bureaucracy's habitual planning and control processes, would have made an organisation like the SANDF more resistant to change than would have been the case if a dynamic strategy-forming method had been followed. ${ }^{90}$ While one may therefore no longer blame defence's strategic management model for its current ineffectiveness, the consequences of its adoption at the start of the SANDF's first transformation still continue to bedevil initiatives towards the second.

\section{Conclusion}

This study maintained that militaries in general (and therefore probably the SANDF in particular) lean towards the design school's approach to strategy formation. When considering their options, defence strategists weigh influences from two external contexts (the functional and societal imperatives) and one internal 
environment (the organisational imperative). Whereas emphasis on the functional imperative will shift a defence force's strategic focus towards military effectiveness, an accentuation of the societal imperative will encourage a concern with the structure, service conditions and management efficiency of a particular military. The organisational imperative, in turn, serves to mediate strategic influences from both the external and the internal environments, and then shapes the armed forces' strategic behaviour accordingly.

During the compilation of a hypothetical strategic management model, the current study identified three feedback loops that allow an organisation to perceive its environment, interpret its implications for strategy formation, decide on an appropriate response, and then act accordingly. While insight into the first two loops certainly contributes to the argumentation of the study, it is an analysis of the third feedback loop that sheds most light on the research problem. When productively utilised, this loop serves as an evolution mechanism that stimulates appropriate responses to the external environment, facilitates organisational learning, minimises entropy, and assists the institution in remaining functionally effective. However, strategists of the design school generally underestimate the impact of the functional and societal imperatives, have less appreciation for the potential effects of changes in the organisation's operational context, and are disinclined to manipulate emergent strategy; ergo, they are less responsive in forming the institution's realised strategy. Two intrinsic qualities of all feedback loops further exacerbate the ensuing risk of organisational obsolescence: the delay between cause and effect, and the fact that all strategic actions have both intended and unintended outcomes.

A cursory interrogation of the South African military's sources of strategic culture revealed that the armed forces have had to adjust to the demands of a single (novel and possibly dichotomous) political culture since the SANDF's inception in 1994. At the same time, the military has had to contend with primarily two (distinctive and probably irreconcilable) military cultures: the conventional, mobile warfare mentality of the defunct SADF, and the revolutionary, people's war paradigm of the obsolete MK. Accordingly, government consistently touted the societal imperative as the highest value in force development, while defence policy took its prime directives from the functional imperative instead (albeit only for the second stage of the implementation of strategy, after the SANDF had achieved the integration of its constituent military forces). In terms of the design school paradigm, defence strategists would have assumed the first, evolutionary stage of transformation as an interim or transient condition and of passing importance in the greater scheme of the implementation of strategy - and thereby underestimated this stage's detrimental impact upon organisational culture, and upon the SANDF's subsequent strategic behaviour. Given that, with the passing of time, MK's strategic 
culture was gaining ascendancy as that of the SADF waned, the value preferences of the defence force generals eventually shifted closer to those that government had espoused all along.

The ambitions of defence policy towards military effectiveness, through its declared combination of ends and means, consequently became less acceptable - or at least less pressing - as the armed forces' strategic culture changed. While major portions of the SANDF's declaratory force development strategy remained unrealised, the organisation's actual transformation strategy maintained most of its momentum, even after the period 2004-2006 when an opportunity arose to enhance military effectiveness again. It seems that, subsequent to achieving its initial, political transformation goals with defence, government has run out of ideological steam when confronted with the realities of an ever-changing security environment. As usually happens, the realised strategy of the SANDF is therefore comprised of a combination of intended strategy (in this case, mainly the societal elements of it) and emergent strategy (most of it unintended and unconstructive, in this instance). From this evidence, the marriage between the SANDF's preferred strategic management model and its acquired strategic cultures has proved to be an unhappy one. This provides a partial explanation for government's apparent bemusement at adopting an intended force development strategy in 1998, achieving its societal component by about 2005, realising undesirable strategic outcomes by 2013, and now finding its defence force in a state of virtual strategic paralysis. Through the combined consequences of a singular political concern with societal imperatives, of a sympathetic organisational culture change over time, of leaving the dogma of 'transformation' unchallenged, and of adopting the habitual planning and control processes of a machine bureaucracy, defence may now be actively resisting change towards military effectiveness rather than promoting it. Whether the Minister of Defence and Military Veterans will therefore be able to turn her statements of political intent into declaratory strategy (arising from Defence Review 2014) any time soon, is a matter of conjecture. It is even more doubtful whether the SANDF, given the dysfunctional character of the interplay between its strategic management model and strategic cultures, has the capacity to convert its strategic intent into realised strategy. With this hypothesis now in the public domain, the article has opened the door to a full-blown validation study.

\section{Endnotes}

${ }^{1}$ Gray, S. Modern strategy. New York: Oxford University Press, 1999, 141.

2 The South African Defence Force, prior to 27 April 1994.

${ }^{3}$ The abbreviation MK is used for Umkhonto we Sizwe (translated as "Spear of the Nation"), the armed force of the African National Congress (ANC) before 
1994. It was the most important revolutionary armed force mobilised against the apartheid state.

${ }^{4}$ Republic of South Africa. "South African Defence Review 2014". 〈http://www.sadefencereview2012.org/publications/publications.htm> Accessed on 21 October 2014.

5 “Speech by Nosiviwe Mapisa-Nqakula, Minister of Defence and Military Veterans on the occasion of the Department of Defence Budget Vote 2013". South Africa Government Online. <http://www.info.gov.za/speech/DynamicAction? pageid=461\&sid=36705\&tid=107903 > Accessed on 21 October 2014 .

${ }^{6}$ Gray, CS. Weapons don't make war: Policy, strategy and military technology. Lawrence, KS: University Press of Kansas, 1993, 67.

${ }^{7}$ Hooker, RD. "“The strange voyage"”: A short précis on strategy". Parameters 42(4)/43(1). Winter/Spring 2013. 62.

${ }^{8}$ Lantis, JS \& Howlett, D. "Strategic culture". In Baylis, J, Wirtz JJ \& Gray, CS (eds), Strategy in the contemporary world $\left(3^{\text {rd }} \mathrm{ed}\right)$, New York: Oxford University Press, 2010, 86.

${ }^{9}$ Gray, Weapons don't make war op. cit., p 3.

${ }^{10}$ Dandeker, C. " Military and society: The problem, challenges and possible answers". King's College, London, 2003. <https://kclpure.kcl.ac.uk/portal/en/publications >Accessed on 21 October 2014.

${ }^{11}$ Schein, E. “ Organizational culture”. American Psychologist 45/2. February 1990. 110. <http:/psycnet.apa.org/journals/amp/45/2/109/>

12 Johnston, AI. "Thinking about strategic culture". Cambridge, MA: Harvard University Press, International Security 19:4, 1995, 46.

${ }^{13}$ Dandeker op. cit, , p. 3.

${ }_{15}^{14}$ Adapted from Lantis \& Howlett op. cit., p. 91.

15 Johnston op. cit., p. 34.

${ }^{16}$ Nielsen, SC. An army transformed: The US Army's post-Vietnam recovery and the dynamics of change in military organizations. Carlisle, PA: US Army War College, 2010, 22-25. http://www.StrategicStudiesInstitute.army.mil/ Accessed on 21 October 2014.

${ }^{17}$ A doctrine or approach to war that emphasises the specific, systemic disruption of the opponent, aimed at collapsing the adversary's will to resist suddenly through the application of superior stratagems.

${ }^{18}$ Fourie, DFS. The defence decision dilemma. Unpublished paper submitted to the Defence Review Committee, 2011, 20.

${ }^{19}$ A doctrine or approach to war that entails military and paramilitary operations in hostile territory, conducted by irregular forces employing light weapons and using hit-and-run tactics.

${ }^{20}$ Gray, Modern strategy op. cit., p. 131.

${ }^{21}$ Lantis \& Howlett op. cit., p. 90.

${ }^{22}$ Ibid., p. 95. 
${ }^{23}$ Baylis, J, Booth, K, Garnett, J \& Williams, P (eds). Contemporary strategy II: The nuclear powers. ( $2^{\text {nd }}$ ed). London: Croom Helm, 1987, p. 2.

${ }^{24}$ Yarger, HR. "The strategic appraisal: The key to effective strategy". In Bartholomees, JB (ed), The US Army War College guide to national security issues ( $4^{\text {th }}$ ed; Vol. 1), Carlisle: US. Army War College Strategic Studies Institute, $2010,50$.

${ }^{25}$ Hooker op. cit., p. 60.

${ }^{26}$ Bartholomees, JB. “ A survey of the theory of strategy”. In Bartholomees US Army War College guide op. cit., p. 17.

27 Ibid.

${ }^{28}$ Gray, Weapons don't make war op. cit., p. 68.

${ }^{29}$ Mintzberg, H. " The Design School: Reconsidering the basic premises of strategic management”. Engineering Management Review 19/3. Fall 1991. 89.

${ }^{30}$ Ibid., pp. 90-91.

${ }^{31}$ Ibid., p. 91.

${ }^{32}$ Mintzberg, H. “ The fall and rise of strategic planning”. Harvard Business Review January-February 1994. 111.

${ }^{33}$ Espejo, R. "The Viable Systems Model: A briefing about organisational structure". 2003. 6.

<http://library.uniteddiversity.coop/Systems_and_Networks/Viable_Systems Model/INTRODUCTION\%20TO\%20THE\%20VIABLE\%20SYSTEM\%2 OMODEL3.pdf $>$ Accessed on 21 October 2014.

${ }^{34}$ Millett, AR \& Murray, W (eds). Military effectiveness. Vol. 1: The First World War. London: Unwin Hyman, 1990, 1.

${ }^{35}$ Brooks, RA \& Stanley, EA (eds). Creating military power: The sources of military effectiveness. Stanford, CA: Stanford University Press, 2007, 9.

${ }^{36}$ Millett \& Murray op. cit., p. 2.

${ }^{37}$ Bernasconi, J. Military effectiveness: A reappraisal. Fort Leavenworth, KS: School of Advanced Military Studies, United States Army Command and General Staff College, 2007, 1.

${ }^{38}$ Farrel, T \& Terriff, T (eds). The sources of military change: Culture, politics, technology. Boulder, CO: Lynne Rienner, 2002, 268.

${ }^{39}$ Brooks \& Stanley op. cit., pp. 16-17.

40 Ibid.

${ }^{41}$ Biddle, S. Military power: Explaining victory and defeat in modern battle. Princeton, NJ: Princeton University Press, 2004, 5.

42 Ibid., p. 11.

43 Ibid.

${ }^{44}$ Kasrils, R. "Progress in transformation". In Cilliers, J (ed), Continuity in change: The SA Army in transition. ISS Monograph Series 26. August 1998. 16-17.

45 Ibid., p. 18.

${ }^{46}$ Ibid., p. 19.

${ }^{47}$ Ibid., p. 18.

${ }^{48}$ Esterhuyse, A. " Getting the job done: Transformation in the South African Military”. Strategic Review for Southern Africa XXXII/1. June 2010. 1-30. 
${ }^{49}$ Vreÿ, F. "From theory to culture: Emergent South African strategic culture”. Journal of Military and Strategic Studies 9/3. Spring 2006/07. 26-28.

${ }^{50}$ Ibid., pp. 24-25.

${ }^{51}$ Cilliers, J (ed). Continuity in change: The SA Army in transition. ISS Monograph Series 26. August 1998. 4. Also see Kasrils op. cit., pp. 15-17.

${ }^{52}$ DefenceWeb 6 July 2011. For example, the chair of the Joint Standing Committee on Defence explained in 2011 "that the lack of an effective exit strategy appeared to be the reason for the lack of progress in transformation in the SANDF".

<http://www.defenceweb.co.za/index.php?option=com_content\&view=articl e\&id=16939: sandf-77-male-72-black\&catid=111:sa-defence \&Itemid=242> Accessed on 21 October 2014.

${ }^{53}$ Kasrils op. cit., p. 17.

${ }^{54}$ DefenceWeb 6 July 2011 op. cit.

${ }^{55}$ Department of Defence and Military Veterans. Annual Report 2012/13, 114.

${ }^{56}$ Ibid., p. 122.

${ }^{57}$ DefenceWeb 6 July 2011 op. cit.

${ }^{58}$ Gray, Modern strategy op. cit., p. 131.

${ }^{59}$ Republic of South Africa. "White Paper on Defence, May 1996". Chapter 2. 7. <http://merln.ndu.edu/whitearticles/SouthAfrica1996.pdf > Accessed on 21 October 2014.

${ }^{60}$ Ibid.

${ }^{61}$ Ibid. Also see Republic of South Africa. "South African Defence Review 2012 (Consultative Draft)". Department of Defence. <http://www.info.gov.za/view/DownloadFileAction?id=163570> Accessed on 21 October 2014.

${ }^{62}$ Williams, R. "Defence in a democracy: The South African Defence Review and the redefinition of the parameters of the national defence debate". In Williams, R, Cawthra, G \& Abrahams, D (eds), Ourselves to know, Pretoria: ISS Africa, 2002, 212.

${ }^{63}$ Farrel \& Terriff op. cit., p. 6.

${ }^{64}$ Schein op. cit., p. 24.

${ }^{65}$ Ibid.

${ }^{66}$ Kasrils op. cit., pp. $18-20$.

${ }^{67} \mathrm{CSADF}$. "Construction and functions of the Joint Military Co-Ordinating Council”. Internal Communication Bulletin 8. 1 February 1994.

${ }^{68}$ Murray, W. “ Does military culture matter? In Lehman, JF \& Sicherman, H (eds), America the vulnerable: Our military problems and how to fix them, Philadelphia, PA: Foreign Policy Institute, 1999, 141. <www.fpri.org/americavulnerable/BookAmericatheVulnerable.pdf> Accessed on 21 October 2014.

${ }^{69}$ Gray, Modern strategy op. cit., p. 52.

70 The SANDF does not make unclassified data regarding former force representation available. However, even a cursory internet scan reveals that the posts of Chief SANDF, Chief of Corporate Staff, all of the service chiefs 
and the vast majority of the division chiefs were occupied by former members of MK in 2013; also that the Chief SANDF and Chief SA Army (the latter commanding by far the largest service, which was also the most committed in military operations past and present) started in the SANDF as human resource practitioners, not as combat officers.

${ }^{71}$ In contrast to the expectation of convergence between two race-associated social cultures at some time in future, one can state the certainty of the demise of the two dominant military cultures. By 2024, any serviceman that had entered the SANDF at age 30 or older in 1994 would, regardless of former force, have reached retirement age.

${ }^{72}$ Mintzberg op. cit., p. 97.

73 Ibid.

${ }^{74}$ SANDF. "Legal position of the forces comprising the SA National Defence Force (SANDF)". Internal Communication Bulletin 4. 6 May 1994; SANDF. "Senior appointments in the NDF". Internal Communication Bulletin 20. 29 June 1994 .

${ }^{75}$ Kasrils op. cit., p. 16.

${ }^{76}$ Cilliers op. cit., p. 4.

${ }^{77}$ Mintzberg op. cit., p. 97.

${ }^{78}$ Cilliers op. cit., p. 2.

${ }^{79}$ Venter, C. “Planning for transformation”. In Cilliers, J (ed), Continuity in change: The SA Army in transition. ISS Monograph Series 26. August 1998. 30 .

${ }^{80}$ Kasrils op. cit., p. 24.

${ }^{81}$ Venter op. cit., pp. 25, 28-29.

${ }^{82}$ Mintzberg op. cit., pp. 97-98.

${ }^{83}$ Venter op. cit., pp. 29-30.

${ }^{84}$ Ibid., p. 26; Kasrils op. cit., pp. 20, 22-23.

${ }^{85}$ Republic of South Africa. "White Paper on Defence, May 1996" op. cit.

${ }^{86}$ Ibid. This reflexive behaviour became even more visible after 2009, when the Minister of Defence implemented measures to substantially improve the remuneration and service conditions of the SANDF.

${ }^{87}$ Mintzberg op. cit., p. 98.

${ }^{88}$ SA Army. Strategic profile of the SA Army 2020. Pretoria: SA Army Office, June 2006.

${ }^{89}$ Parliamentary Monitoring Group. "Defence update 2005, first report". <http://www.pmg.org.za/docs/2005/050614 reportupdate.htm> Accessed on 21 October 2014.

${ }^{90}$ Mintzberg op. cit., p. 98. 